\title{
DESCRIPTIONS OF RECENTLY DISCOVERED CLADOCERA FROM NEW ENGLAND.
}

\author{
By Alfred A. Doolittle, \\ Of the Central High School, Washington, District of Columbia.
}

The collections of Entomostraca made by the writer for the United States Bureau of Fisheries in its investigations of the New England lakes contain several Cladoceran forms which seem to be new. This paper describes more fully and with drawings a recently established genus and its type-species and another recently discovered species of a different family, a preliminary diagnosis of which has already appeared. ${ }^{1}$

\section{Family LYNCODAPHNIIDE. \\ Genus PAROPHRYOXUS Doolittle.}

Parophryoxus Doolittle, Proc. Biol. Soc. Washington, vol. 22, 1909, p. 153.

This genus is erected to include the new species P. tubulatus Doolittle, described below.

Female.-Form ellipsoidal; dorsal and ventral margins convergent and produced posteriorly; posterior margin a small fraction of greatest height. Upper or dorsal posterior angle often prominent, but not produced as a spine. Ventral margin sinuate, middle third setiferous. Head viewed laterally, evenly rounded; produced into distinct beak. Cervical sinus present. Fornix well developed, with a horizontal portion running over base of second antenna and eye, and a vertical portion running well toward end of rostrum, resembling Ophryoxus. A median keel from tip of rostrum to posterior end of test. Sides of test concave.

Eye moderate; macula nigra or ocellus quadrangular, situated in base of rostrum; smaller than eye. First antennæ or antennules attached to apex of rostrum; long, cylindrical; a sensory seta near base of each, and several unequal olfactory setæ distally; otherwise without conspicuous armature. Second antenna with basal segment annulated, and with two setæ and one spine; rami with setæ $\frac{0003}{003^{3}}$, spines $\frac{0101}{001}$; setæ and rami about equal, reaching to posterior third. Labrum with anterior and posterior lobes encircling an open-

1 New Cladocera from New England. Proc. Biol. Soc. Washington, vol. 22, pp. 153-156, July $28,1909$.

Proceedings U. S. National Museum, Vol. 41-No. 1848. 
ing, the labrum thus appearing fenestrated. Maxillæ with three teeth. Thoracic appendages or legs six, conforming closely to family type. Postabdomen long, tapering, triangular; armature very weak, consisting of a double row of a few tiny spines distally upon upper or posterior border, and laterally of a few fasciculi of spicules. Caudal claw long, slightly curved, with two small spines at base; claw ciliated on both concave and convex borders.

Intestine coiled, hepatic cæca present.

Male.-Form similar to female. First antennæ or antennules each with long sensory seta; second antennæ each with additional seta upon each of the first and second segments of the lower or inner ramus, therefore, setæ $\frac{0003}{113}$, spines $\frac{0101}{001}$. Hook upon first leg. Postabdomen almost smooth; sperm duct terminal.

Though resembling Ophryoxus in side view quite remarkably, it is necessary to establish this genus as the following parallel shows.

\begin{tabular}{|c|c|c|}
\hline & Parophryoxus. & Ophryoxus. \\
\hline General aspect.......... & Ellipsoidal........... & Quadrangular. \\
\hline Head.................... & Evenly, convexly rounded........... & Truncated, concave. \\
\hline Dorsal margin........... & $\begin{array}{l}\text { Sloping downward and produced with- } \\
\text { out spine. }\end{array}$ & $\begin{array}{l}\text { Directed upward and with prominent } \\
\text { spine. }\end{array}$ \\
\hline Ventral margin... & Sinuate, middle third setigerous....... & Straight, setigerous throughout. \\
\hline Posterior margin........... & Low, and at end of tubular extension... & High, no extension of test. \\
\hline Sides.................. & 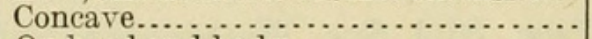 & Convex. \\
\hline Keel.................. & On head and body ............ & Lacking. \\
\hline Antennules............ & Almost smooth........... & Heavily bristled. \\
\hline Antennæ, female.... & Setæ $\frac{0003}{003}$, spines $\frac{0101}{001} \ldots \ldots \ldots \ldots \ldots$ & Setæ $\frac{0003}{11}$ spines $\frac{0101}{001}$. \\
\hline Labrum ....... & W ithout fleshy organs, fenestrated.... & $\begin{array}{l}113 \\
\text { With fleshy organs, not fenestrated. }\end{array}$ \\
\hline 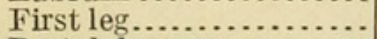 & Without maxillary process........... & With maxillary process. \\
\hline Postabdomen........... & Armature obsolescent................. & Armature very strong. \\
\hline Caudal claw.............. & Convex border ciliated................ & Convex border smooth. \\
\hline Rectal cæca........... & 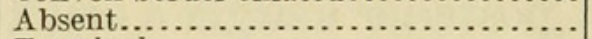 & Present. \\
\hline Opening of sperm duct.. & Terminal............. & Middle of anterior border. \\
\hline
\end{tabular}

Type-species.-P. tubulatus Doolittle.

The name was chosen to indicate its relationship to other Lyncodaphniidæ by Prof. E. A. Birge, to whom also the writer is indebted for calling his attention to the proper place among the Cladocera of specimens of this genus and to important characteristics.

PAROPHRYOXUS TUBULATUS Doolittle.

Plates $13,14,15$, and 16.

Parophryoxus tubulatus Doolitrle, Proc. Biol. Soc. Washington, vol. 22, 1909, p. 153.

Female.-Length $1.15 \mathrm{~mm}$; height one-half to two-thirds the length. General form, long oval. Upper and lower margins curved nearly symmetrically; however, the middle third of lower margin flattened, sinuate, bearing ciliated setæ, long in the middle part and diminishing rapidly anteriorly and posteriorly. The convergent dorsal and ventral margins and two sides produced to form a rather conspicuous tube posteriorly, the open end of which constitutes the free posterior margin. Posterior margin one-fifth to one-seventh of 
greatest height; ciliated. Upper angle sometimes accentuated, especially in immature specimens, but never spined. Width from side to side one-fourth length; suddenly narrowing anteriorly at head, and more gradually posteriorly at the tubular part. Keel low, of uniform height throughout. Upper and lower margins of the concavity of sides thickened to form obvious ridges as seen from the front, and traceable upon the sides of the test in lateral and dorsal views. The opening or gape between the valves ventrally, rhomboidal or lozenge-shaped in anterior two-thirds, with sides of the figure equal, straight; angles well defined. In posterior one-third, that is, in the tubular portion, margins of valves ventrally parallel and nearly touching. Test marked with delicate hexagonal meshes.

Outline of head in side view semicircular; rostrum truncated. The horizontal limb of fornix arising opposite the cervical sinus, curving upward over base of second antenna and eye, then curving downward with slight sinuosity almost to end of rostrum, very similar to the course taken in Ophryoxus. Viewed from above, fornix broad with parallel sides; from the front, narrowed. Eye moderate in size, with few facets; macula nigra or ocellus nearly as large as eye, in base of rostrum. First antenna or antennule cylindrical, slightly smaller in middle than at ends, the base swollen posteriorly; length ten times average diameter; lateral seta one-fourth distance from base; three of the terminal olfactory setæ long, subequal, about two-thirds length of antennule, and four times the length of the remaining six setæ. Each antennule with two longitudinal rows of seven or more equidistant minute denticles; from side view one row appearing near anterior border, and one row near the posterior border. Second antenna long, basal segment annulated, bearing upon a tubercle at the middle of upper border two delicate setæ with fleshy first joints; distally upon lower border a strong spine. Rami armed typically for females of the genus; rami reaching to end of antennules or to first third of test; setæ equaling the rami, reaching to posterior third of test. The anterior lobe of labrum slender, backwardly curved; the posterior lobe also slender, but anteriorly curved or hooked, almost touching the anterior lobe, thus inclosing an oval space or fenestrum, opposite to the mandibles, of the size and orientation of their grinding surfaces, so that the mandibles oppose each other through the opening. Mandibles without noteworthy features. Maxillæ with basal arm narrowed distally; teeth three, set at an angle of $60^{\circ}$ with base, subequal, distal largest, and its convex border sparsely ciliated.

Thoracic appendages or legs, six similar to those of other Lyncodaphniidæ, especially Ophryoxus gracitis G. O. Sars, yet differing from Ophryoxus and agreeing with all other genera of the family in the absence of the maxillary process upon the first pair. The spines and setæ of the first leg are: upon the protopodite, a cluster 
of hairs and two ciliated setæ; upon exopodite, one short and one long seta; anterior or outer branch of endopodite encircled with three rows of short stiff hairs, three strong terminal setæ, one of them two-segmented; the posterior or inner branch of endopodite plainly three-lobed, each lobe bearing, respectively, beginning anteriorly, two short heavy ciliated setæ or spines, three still stronger ciliated spines, and four more delicate two-segmented setæ. The second to fifth legs almost identical with those of Ophryoxus, but with the geniculate setæ upon maxillary processes of third, fourth, and fifth very strongly developed. Sixth leg asymmetrical; on lower posterior border a protuberance with two fasciculi of long cilia, ventrally a row of cilia; on anterior border cilia, fine and numerous below, sparse and stronger above.

The postabdomen slender and triangular, the two converging borders irregularly sinuous; about three short spines upon the flexible basal part of the superior or posterior border; anal setæ two, sparsely ciliated; further armature lacking, except for double row distally of about eleven small obsolescent spines, and laterally two or three fasciculi of five to eight delicate cilia each, forming a line approximately parallel to the posterior border. Terminal claw long, nearly or quite half the length of postabdomen, evenly but slightly curved; at base two small subequal teeth, the distal larger; externally at base a row of six small denticles, distal to which the row is continued to the tip with delicate cilia; internally there is a similar row, but with a group of larger cilia instead of denticles; on convex border a row of cilia, distinct at base, but smaller and appressed to the claw toward the tip.

Intestine flexed once upon itself and coiled once in the body; hepatic cæca small; rectum large without cæca.

Male.-Immature males only have been collected. The most advanced specimens are assumed to show most clearly the male structure.

Form, proportion, and general structure essentially as in females of equal development, with the following distinctive details. First antennæ or antennules with conspicuous offset or prominence as in Bosmina, on anterior margin, one-fourth distance from base, the angle of which bears a seta reaching well toward end of antennule. The anterior border of antennule distal to offset, with five to eight slight notches or traces of segmentation in youngest specimens. Second antennæ or antennæ proper with seta upon the proximal segment of lower or inner ramus reaching just to or beyond the seta upon the penultimate segment, these two setæ being distinctive for males.

The hook of first thoracic leg strong, slightly curved. The number of obsolescent spines or spicules of posterior or distal border of postabdomen reduced to about three. In some of the most advanced 
specimens the end of the postabdomen has withdrawn or shrunken from the exoskeletal sheath, apparently showing the opening of the sperm duct, developing for a molt soon to occur, terminal and dorsal to the caudal claw.

Color light yellow; test and tissues transparent.

Measurements of an egg-bearing specimen taken from Anonymous Pond (Crystal Lake), Maine, United States of America, are:

$\mathrm{mm}$.

Length $\ldots \ldots \ldots \ldots \ldots \ldots \ldots \ldots \ldots \ldots \ldots \ldots$

Maximum height .............. .82

Posterior height ................ 12

Meshes, diameter...........021-.018

Eye, diameter

0137

Antennules, length ............. 0. 20

Antennules, diameter........... .02

Postabdomen, length............ . 24

Terminal claw, length.......... . 12

Ocellus, diameter.............. .0112

Type.-Cat. No. 42781, U.S.N.M.

Type-locality.-Anonymous Pond (Crystal Lake), Maine, September $5,1908$.

Occurrence.-Taken frequently and singly in weedy shallow parts of Umbagog Lake, Maine and New Hampshire, August, 1905; Sebago Lake, Maine, July, August, September, 1906, 1907, 1908; Anonymous Pond, Maine, September, 1908.

\section{Family CHYDORID E Leach (LYNCEIDE Baird).}

CHYDORUS BICORNUTUS Doolittle.

Plates 17, 18, and 19.

Chydorus bicornutus Doolittle, Proc. Biol. Soc. Washington, vol. 22, 1909, p. 154.

Female.-Length of body 0.50 to $0.62 \mathrm{~mm}$; height of body fivesixths the length. General form from side view circular oval, somewhat truncated posteriorly, posterior margin sparsely spined. Ventral margin sinuate, with sharp ventral curvature at the middle; setigerous margin turned inward, with short, delicate ciliated setæ interlocking across the ventral opening or gape between the valves. Seen from above, body nearly twice as long as broad, oval, broadest at middle, rounded broadly anteriorly, tapering posteriorly. In front view general form oval, broadest at upper one-fourth, dorsal margin slightly concave on each side. The ventral margins of the valves nearly approximate in posterior one-third, but slightly divergent at posterior one-third and running forward nearly parallel.

The form of the test of the body proper is modified by a most extraordinary exoskeletal development of horns, ridges, and deep rectangular and hexagonal cells, of which the exoskeletal development of $C$. faviformis Birge gives a suggestion. From the middle of each valve of the test there stands out horizontally a large horn, slightly curved posteriorly. This horn varies in length from one-fifth of to a little more than the width of the body. From this obvious 
structural feature the species has derived its specific name. From this horn there originate two sets of ridges, one running anteriorly and one dorsally. Taking their origin well toward the tip, one on the upper or dorsal margin of the horn and another on the lower or ventral margin, there run forward two ridges of the first set. The upper one, the superior spinal ridge, continuing across the base of the rostrum merges with other ridges which have a downward course and disappears at the tip of the rostrum. The lower one, the inferior spinal ridge, also passes forward; it diminishes in height and merges with the general level of the honeycomb cells at the upper end of the anterior border of the valve. The space thus bounded by the superior and inferior spinal ridges of each side, the lateral spinal cleft, is free of structures. Similarly there run dorsally from horn to horn two ridges of the second set, the anterior and the posterior interspinal ridges, taking their origins halfway to the tip of the horn, bounding the interspinal cleft, which runs from horn to horn over the back. This cleft also is free from structures and divides the dorsum into anterior and posterior portions. In the middle of the space anteriorly is a clearly defined area, to be called the anterior dorsal area, bounded laterally by high dorsal ridges which converge anteriorly with sharp lateral and apical angles. This area is divided into large cells. The arrangement of these cells usually conforms to the following plan: occupying the anterior angle is a single cell, then four transverse rows of cells with two and three cells in each row alternating; behind the last of these rows is a large pentagonal cell, and between this cell and the anterior interspinal ridge is a row of several smaller cells.

From the antero-lateral angles of the anterior dorsal area just discussed there runs laterally and downward on each side a high ridge, the cervical ridge, to the superior spinal ridge. The lateral space bounded by the two ridges last mentioned, the anterior dorsal area, and the lateral parts of the anterior interspinal ridge is occupied by deep cells; large rectangular cells adjoining the dorsal and cervical ridges, but hexagonal and smaller cells toward the other boundaries.

From the anterior angle of the anterior dorsal area there runs forward in the median line a short occipital ridge which divides right and left into the facial ridges. The facial ridge on each side continues parallel to the cervical ridge and meets the superior spinal ridge at the base of the rostrum, where their identity merges. Between the cervical ridge, on the one hand, and the occipital and facial ridges on the other, there pass parallel partitions dividing the space into long, deep, rectangular cells, some seven or eight in number. Included between the two facial ridges is the facial area. In the center of this is a small deep cell, the ocular cell, immediately behind which is the compound eye. From the ocular cell and from small 
cells lateral to it there radiate to the facial ridges a number of partitions further dividing the facial area into long radiating cells, somewhat rectangular in form and corresponding in number to the cells external to the facial ridges. Immediately ventral to the ocular cell there are four cells, behind whose common meeting point is the macula nigra or ocellus. To the tip of the rostrum there run the ridges already referred to and a converging series of elongated cells diminishing in height distally.

Each valve of the test supports four prominent ridges below the horn, some especially conspicuous from front and from dorsal view. Those of each side have their origin very near each other at the upper end of the anterior border of the test. Their general direction is parallel to the ventral edge, two of them upon or near the margin, and two a little removed from the margin. They will be called, taking them in order from the margin, the marginal, submarginal, inferior valval, and superior valval ridges. The superior valval ridge standing out at right angles to the test is a very conspicuous object in front view, and also from dorsal view its posterior part, which is seen to end one-fourth from the posterior end of test. The submarginal ridge takes its origin where the inferior spinal ridge is lost among the hexagonal cells at the upper end of the anterior margin of the valve, crosses the origins of the valval ridges, and merges with the marginal ridge midventrally. The inferior valval ridge and the marginal ridge follow the directions already indicated for them, and parallel to those just discussed, and fuse opposite the superior angle of the posterior margin as the margino-valval ridge. At this point it flares outward slightly and running forward on the back joins the posterior interspinal ridge. The space thus inclosed between these united ridges of each side is the posterior dorsal area. Across the anterior end of the area are three large cells. The remaining part of the area is open. The portion of the valves included between the two clefts and the valval ridges is filled with hexagonal cells, larger dorsally and posteriorly and smaller anteriorly. From ridge to adjacent parallel ridge high partitions pass, dividing the intervening space into deep rectangular cells.

Rostrum long, acute, often included between the ridges upon the anterior margins of the valves; the anterior portion of the superior spinal ridge forms a sort of fornix across its base. Eye large; ocellus one-half its diameter, in the base of rostrum. Antennules slender, failing to reach tip of rostrum by about their length; sensory seta in angle upon anterior margin distally; five or more subequal, short, olfactory setæ apically. Antennæ short, not reaching to end of antennules. Rami with setæ $\frac{003}{013}$, with spines $\frac{001}{000}$; one of the distal setæ of lower or inner ramus one-third the length of the remaining: Labrum from side view with short, blunt anterior lobe, and elongated, fingerlike, posterior lobe, directed ventro-posteriorly, tipped with 
short bristles or cilia; from anterior view labrum with anterior lobe broadly triangular, keeled dorsally, and posterior lobe narrower, sides sinuate but approximately parallel, the tip trilobed, the middle lobe bearing the bristles or cilia. Mandible not distinctive. Maxilla with two teeth, densely bristled; the basal arm broad, its distal boundary and outer tooth forming a continuous semicircular curve.

Legs or thoracic appendages five, conforming strictly to generic type.

Postabdomen broad, length medium; dorsal margin concave beyond anal angle, and broadly rounded at end; proximal half ciliated, distal half with double row of twelve teeth in each row, quite strong: for this genus, diminishing slightly distally. Laterally a row of cilia from base of caudal claw to a point near anal angle. Terminal claw strong, slightly curved and crumpled; concave border ciliated to tip; basal spines two, the distal twice the size of the proximal.

\section{Measurements.}

\begin{tabular}{|c|c|c|c|c|c|c|c|}
\hline \multirow{3}{*}{ 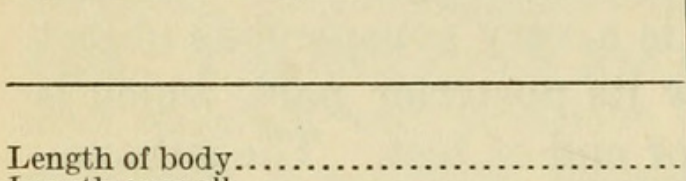 } & \multicolumn{7}{|c|}{ Chydorus bicornutus from Sebago Lake. } \\
\hline & $m m$. & $m m$. & $m m$. & $m m$ & $m m$. & $m m$. & $m m$. \\
\hline & 0.400 & $\begin{array}{l}0.475 \\
.550\end{array}$ & 0.000 & $\begin{array}{r}0.020 \\
.680\end{array}$ & 0.020 & 0.000 & 0.620 \\
\hline Width of body.. & .260 & .280 & .380 & .400 & .410 & .440 & .480 \\
\hline Width over all. & .900 & .550 & .740 & .520 & .600 & 1.020 & .720 \\
\hline Height of body & .320 & .400 & .460 & .500 & .480 & .520 & .560 \\
\hline Height over all & .440 & .500 & .560 & .660 & .600 & .720 & .730 \\
\hline Length of horn. & .340 & .170 & .240 & .060 & .140 & .320 & .140 \\
\hline Highest ridge. & .080 & .100 & .075 & .100 & .120 & .125 & .120 \\
\hline Diameter of largest hexagonal cell. & .035 & .040 & .050 & .050 & .040 & .060 & .075 \\
\hline Diameter of average hexagonal cell & .025 & .025 & .030 & .035 & .030 & .030 & .050 \\
\hline Depth of average cell..... & .020 & .040 & .070 & .040 & .030 & .060 & .040 \\
\hline Length of terminal claw. & .050 & .060 & .065 & .070 & .070 & .070 & .075 \\
\hline Length of postabdomen from anal setæ to claw. & .165 & & .140 & .235 & .190 & .250 & .245 \\
\hline
\end{tabular}

The variations in proportions are at once apparent; the greatest extremes are in the length of the horn. An analysis of these proportions expressed in percentages of the length shows no significant correlation. On the whole, there are more minimum proportions among the smallest specimens and more of the maximum proportions among the larger specimens. But the totals of the proportion percentages are larger for the smaller individuals and smaller for the larger individuals, with an exception in each group. The $0.60 \mathrm{~mm}$. specimen is the only one not extreme in any of the structures measured; each of the others is extreme, maximum or minimum, in from three to six proportions measured. The variation is dependent upon locality rather than upon age or size. Specimens from one collecting station (mouth of Northwest River) furnished the long-horned specimens; another locality (mouth of Sucker Brook) the short-horned individuals. Specimens from other localities seem to be more average in this particular. Specimens from New Jersey are of the short-horned type.

Eggs, two.

Male.-Unknown.

Color, yellowish. 
The honeycomb cells are remarkably free from attached algæ or protozoa or debris, though some of these are observed at times. C. faviformis Birge, which occurs associated with the form here described, is often loaded with algæ and protozoa.

Occurrence.-Taken frequently but not in numbers from weedy shallow parts of Umbagog Lake, Maine, and New Hampshire, 1905, July, August; Sebago Lake, Maine, 1906, 1907, 1908, July, August, September; Panther Pond, Maine, 1906, August; Songo River, Maine, 1906, July; Grover Mill Pond, Princeton, New Jersey, 1909, September; 1910, August.

Type.-Cat. No. 42782, U.S.N.M.

Type-locality.-Sebago Lake, Maine, August 19, 1907.

\section{EXPLANATION OF PLATES.}

Plate 13.

Fig. 1. Parophryoxus tubulatus, female from Umbagog Lake, Maine and New Hampshire, August, 1906. Lateral view. $\times 58$.

2. Do. Rostrum and Antennule. $\times 233$.

3. Do. Antenna. $\times 233$.

4. Do. Postabdomen. $\times 233$.

Plate 14.

Fig. 1. Parophryoxus tubulatus, female from Anonymous Pond, Maine, September, 1908. Lateral view. $\times 58$.

2. Do. Dorsal view. $\times 58$.

3. Do. Anterior view. $\times 58$.

4. Do. First leg. $\times 233$.

5. Do. Second leg. $\times 233$.

6. Do. Third leg. $\times 360$.

Lettering: $d$, exopodite; $e, e^{\prime}, e^{\prime \prime}$, endopodite and its branches; $m x$, maxillary process.

Plate 15.

Fig. 1. Parophryoxus tubulatus, female from Anonymous Pond, Main€, September, 1908. Fourth leg. $\times 360$.

2. Do. Fifth leg. $\times 360$.

3. Do. Sixth leg. $\times 360$.

4. Do. Head, lateral view. $\times 133$.

5. Do. Maxilla. $\times 400$.

6. Do. Postabdomen. $\times 133$.

Lettering as under Plate 14.

Plate 16.

Fig. 1. Parophryoxus tubulatus, marking of shell, female. $\times 633$.

2. Do. Male from Anonymous Pond, Maine, September, 1908. Lateral view. $\times 94$.

3. Do. Anterior view. $\times 133$.

4. Do. Juvenile male. Lateral view. $\times 94$.

5. Do. End of postabdomen, the shrunken tissues showing position of sperm duct. $\times 270$.

Plate 17.

Fig. 1. Chydorus bicornutus, female from Sebago Lake, Maine, July, 1908. Lateral view, antenna not shown. $\times 127$.

2. Do. Dorsal view. $\times 127$. 
KEY TO LETTERING.

$A D A$ Anterior dorsal area.

$A I R$ Anterior interspinal ridge.

$B O$ Body outline.

$C R$ Cervical ridge.

$D R$ Dorsal ridge.

$F A$ Facial area.

$F R$ Facial ridge.

$H$ Horn.

$I C$ Interspinal cleft.

$I S R$ Inferior spinal ridge.

$I V R$ Inferior valval ridge.
$L S C$ Lateral spinal cleft. $M R$ Marginal ridge.

$M V R$ Margino-valval ridge.

$O C$ Ocular cell.

$O R$ Occipital ridge.

$P D A$ Posterior dorsal area.

$P I R$ Posterior interspinal ridge.

$S S R$ Superior spinal ridge.

$S R$ Submarginal ridge.

$S V R$ Superior valval ridge.

\section{Plate 18.}

Fig. 1. Chydorus bicornutus, female from Sebago Lake, Maine, July, 1908. Anterior view. Lettering as on Plate 17 . $\times 127$.

2. Do. Antenna. $\times 233$.

3. Do. Antennule. $\times 400$.

4. Do. Lower part of head, lateral view. $\times 233$.

5. Do. Labrum, anterior view. $\times 233$.

6. Do. Maxilla. $\times 400$.

\section{Plate 19.}

Fig. 1. Chydorus bicornutus, female from Sebago Lake, Maine, July, 1908. First leg. $\times 400$.

2. Do. Second leg. $\times 400$.

3. Do. Third leg. $\times 400$.

4. Do. Fourth leg. $\times 400$.

5. Do. Fifth leg. $\times 400$.

6. Do. Postabdomen. $\times 233$.

Lettering: $d$, exopodite; $e, e^{\prime}, e^{\prime \prime}$, endopodite and its branches; $m x$, maxillary process. 


\section{$2 \mathrm{BHL}$ Biodiversity Heritage Library}

Doolittle, Alfred A. 1911. "Descriptions of recently discovered Cladocera from New England." Proceedings of the United States National Museum 41(1848), 161-170. https://doi.org/10.5479/si.00963801.41-1848.161.

View This Item Online: https://www.biodiversitylibrary.org/item/94484

DOI: https://doi.org/10.5479/si.00963801.41-1848.161

Permalink: https://www.biodiversitylibrary.org/partpdf/68137

\section{Holding Institution}

Smithsonian Libraries

\section{Sponsored by}

Smithsonian

\section{Copyright \& Reuse}

Copyright Status: Public domain. The BHL considers that this work is no longer under copyright protection.

This document was created from content at the Biodiversity Heritage Library, the world's largest open access digital library for biodiversity literature and archives. Visit BHL at https://www.biodiversitylibrary.org. 